\title{
LA REINA GINEBRA Y SU SOBRINO: LA DAMA, EL PAJE, LA TORMENTA Y EL MANTO (METÁFORAS LÍRICAS Y MOTIVOS NARRATIVOS)*
}

\author{
José Manuel Pedrosa \\ Universidad de Alcalá
}

Las investigaciones literarias acerca de las metáforas líricas y de los motivos narrativos parecen haber ido, hasta hoy, cada una por su lado, y haber ocupado a categorías muy diferentes de filólogos, presuntos especialistas en verso los unos, presuntos especialistas en prosa los otros. Como si lo lírico y lo narrativo fuesen dominios separados, autónomos, y como si pudiesen ser considerados desde especializaciones diferentes sin peligro de que se desvirtúe gravemente su naturaleza. No soy capaz de citar ni un solo estudio teórico que haya abordado las relaciones que podría haber entre las metáforas que supuestamente se entretejen en los discursos líricos y los motivos que presuntamente se articulan en los discursos narrativos, ni que haya evaluado la posibilidad de que existan cruces de metáforas y de motivos o de que pueda hablarse de metáforas con proyecciones narrativas o de motivos con rasgos líricos.

Y sin embargo, la metáfora ¿lírica? y el motivo ¿narrativo? pueden ser definidos, los dos, como unidades discursivas con significados intensos y acuñados y con funciones relacionales indispensables para la construcción del poema o del relato; es decir, como artefactos semánticos y sintácticos especiales por su acusado perfil significativo interno y por su esencial función de articulación externa. La noción, sin duda general y superficial, de que la metáfora es una pieza básicamente lírica y significativa del discurso (como si mirara para adentro), y de que el motivo es básicamente narrativo

\footnotetext{
* Este artículo se publica dentro del marco de la realización del proyecto de I+D del Ministerio de Ciencia e Innovación titulado Historia de la métrica medieval castellana (FFI2009-09300), dirigido por el profesor Fernando Gómez Redondo, y del proyecto Creación y desarrollo de una plataforma multimedia para la investigación en Cervantes y su época (FFI2009-11483), dirigido por el profesor Carlos Alvar. También como actividad del Grupo de Investigación Seminario de Filología Medieval y Renacentista de la Universidad de Alcalá (CCG06-UAH/HUM-0680). Agradezco la ayuda que me han prestado José Luis Garrosa, Eva Belén Carro Carbajal, Óscar Abenójar, José J. Labrador Herraiz, Ralph A. DiFranco y Agustín Clemente Pliego.
} 
y sintáctico (como si mirara para afuera), no resiste ningún análisis atento ni cuidadoso. Toda metáfora se inscribe dentro de un contexto verbal más amplio en el que interactúa, por lo general, con otras metáforas; y todo motivo tiene, a su vez, unas interioridades semánticas densas y complejas, aunque se engarce también con otros motivos. Tampoco están bien justificados el prestigio casi carismático que entre los filólogos tiene la metáfora, a la que se considera pieza absolutamente central y definitoria del discurso poético, y el desinterés que rodea al motivo, al que se considera pieza solo auxiliar y estereotipada del discurso narrativo. La segregación estratégica de verso y de prosa, la aristocracia presunta de la metáfora y el servilismo hipotético del motivo, la intensidad semántica de la una y la funcionalidad sintáctica del otro son lugares comunes y simplistas de los críticos que muchos discursos literarios primarios desmienten vigorosamente, sobre todo cuando son de extracción básicamente oral y tradicional y cuando son analizados con sesgos amplia y flexiblemente comparatistas, como intentaré hacer aquí.

La cuestión es lo suficientemente compleja como para que no pueda ser dilucidada en un simple artículo, pero es posible que las metáforas-motivos que van a asomar insistentemente en estas páginas, las cuales van a tratar no se sabe muy bien si sobre poemas narrativos o si sobre narraciones en verso, sirvan al menos para poner al descubierto cruces e intercambios fecundos, categorías graduales e híbridas operativas, interrogantes que habrá que seguir evaluando en reflexiones futuras.

\section{¿Dido y Eneas como modelo?}

Relata Virgilio, en su Eneida IV: 117-126, el modo en que la diosa Juno urdió un plan para que Dido, reina de Cartago, y Eneas, prófugo de la destruida Troya acogido en el reino norteafricano de Dido, encontrasen el momento -una jornada de caza-, el lugar -un bosque- y la ocasión -una tempestad súbita que les apartó del cortejo que les acompañaba- más propicios para consumar la unión amorosa que los dos deseaban:

Proyectan salir juntos de caza al bosque Eneas

y la desventurada Dido mañana mismo, cuando despunte el sol y desvele la tierra con sus rayos. En tanto corretean los monteros y acordonan los sotos con sus redes, yo arrojaré sobre ellos un negro turbión de aguas cargado de granizo y haré que el cielo entero retumbe al estampido de los truenos. 
Huirá la comitiva envuelta en sombras de noche.

Juntos Dido y el caudillo troyano

irán a refugiarse en una misma cueva.

Estaré yo presente y si puedo contar con tu aquiescencia, uniéndolos allí con lazo estable le daré al troyano por esposa.

Será éste el himeneo ${ }^{1}$.

Los acontecimientos se fueron desarrollando de acuerdo con las previsiones de la diosa esposada con Júpiter. Acaso, también, con el diseño de lo que, ya en época de Virgilio, podía ser un tópico narrativo heredado, una especie de escenografía migratoria, adaptable, intercambiable en marcos literarios diversos: el del encuentro amoroso de una mujer y un varón de condiciones sociales diferentes (elevada la de ella, inferior la de él), extraviados en el campo, separados de los suyos y unidos por la necesidad de afrontar juntos el destemplado fragor de la tormenta:

En tanto empieza el cielo a estremecerse en confuso zumbido fragoroso.

Le sigue un turbión de agua mezclado de granizo. La comitiva

y los mozos troyanos y el dardanio nieto de Venus, todos desbandados

van huyendo a través de los campos en busca cada cual de amparo a su terror.

Los torrentes irrumpen desatados de los montes. En una misma cueva

buscan refugio Dido y el caudillo troyano. Dan la señal la Tierra, la primera, y Juno, valedora de las nupcias.

Brillaron luminarias en el cielo, testigo de la unión (Eneida IV:160-167).

El amor que desde hacía tiempo ardía en el corazón de la reina Dido encontró, así, ocasión perfecta para ser manifestado y consumado. A partir de entonces,

Dido ya no se cuida de apariencias ni atiende a su buen nombre, ni se imagina el suyo amor furtivo. Lo llama matrimonio.

Usa este nombre por velar su culpa. Al instante la Fama va corriendo por las grandes ciudades de Libia. No hay plaga más veloz (Eneida IV:169-172).

La fama del encuentro amoroso de la reina Dido -ardientemente enamorada, pese a que había prometido fidelidad a la memoria de su difunto esposo Siqueo- y del desheredado Eneas traspasó con ímpetu las fronteras de Libia, y llegó a convertirse en discurso repetido, en modelo clásico e inspirador de muchos otros en tiempos y lugares muy distintos.

${ }^{1}$ Virgilio, Eneida, trad. Javier de Echave-Susaeta, Madrid, Gredos, 1992, IV:117-126. 


\section{«Por los bosques de Cartago...»}

Modelo inspirador, por ejemplo, de un romance español de mediados del siglo XVI (vio la luz en el Cancionero de romances de 1550 y en la Rosa de amores de Timoneda, de 1573) que contamina el argumento de la Eneida con elementos absolutamente apócrifos, como la arbitraria alusión a un incongruente «sobrino de la reina» o, sobre todo, el intenso y apasionado episodio del manto encubridor de los amores silvestres, que tienden llamativos puentes de semejanza hacia el romance de La reina Ginebra y su sobrino (estrictamente coetáneo del de Por los bosques de Cartago) al que muy pronto atenderemos:

Por los bosques de Cartago salía a montería la reina Dido y Eneas con muy gran caballería; un sobrino de la reina, y Junio Ascanio que los guía por la dehesa de Juno, donde más caza salía. Preguntando iba la reina Ascanio qué tal venía, y si se acuerda de Troya, si vio cómo se perdía. Eneas tomó la mano, por el hijo respondía:

- Pues mandáis, reina Dido, renovar la llaga mía, ya os conté cómo vi a Troya, que por mil partes ardía: vi las doncellas forzadas, muerta la caballería, y a Hécuba reina troyana, nadie no la socorría. Sus hijos ya sepultados, Príamo no parecía; a Casandra y Policena muertas cabe sí tenía. Elena quedaba viuda mil veces la maldecía. Eneas que esto contaba, un ciervo que parecía; echó mano a su aljaba una saeta le tira.

El golpe le dio en vano, el ciervo muy bien corría.

Pártense los cazadores, síguelo el que más podía; la reina Dido y Eneas quedaron sin compañía. Tomárala por la mano, con turbación le decía: — ¡Oh, reina, cuán mejor fuera en Troya perder la vida! Los tristes campos de Frigia, fueran sepultura mía; Héctor, Troílo y Paris tuviérales compañía. ¡Oh reina Pantasilea, flor de la caballería!, más envidia he de tu muerte, que deseo la vida mía. Estas palabras diciendo muchas lágrimas vertía. La reina le dijo a Eneas: -Esforzaos por cortesía, que los muertos sobre Troya rescatar no se podían. - No lloraba yo los muertos, lloro la desdicha mía, que me escapé de los griegos y a las tus manos moría; 
que tu grande hermosura de amor me quita la vida.

-Falso es tu atrevimiento -la reina le respondía-,

Eneas, vete a tus naves, sal de esta tierra mía;

que la fe que di a Deyphebos yo no la quebrantaría.

Ellos en aquesto estando, el cielo se revolvía:

las nubes cubren el sol, que gran escuridad hacía;

los relámpagos y truenos en gran miedo los metía;

el granizo era tan grande que sin piedad llovía.

La reina con gran pavor del palafrén se caía.

Eneas bajó con ella, y con el manto la cobría.

Mirando hacia todas partes, una cueva vio vacía;

tomóla en los sus brazos en la cueva la metía.

El aposento era estrecho, revolver no se podía.

Mientras la reina en sí tornaba, Eneas se desenvolvía;

apartóle paños de oro, los de lienzo l’encogía.

Cuando la reina en sí tornó de amores se sintió herida.

— ¡Oh traidor, hasme burlado! ¿Cuál tratas la honra mía?

Complida tu voluntad, olvidarme has otro día

y si así lo has de hacer, Eneas, yo misma me mataría ${ }^{2}$.

\section{La reina Ginebra y su sobrino}

No es posible alcanzar certezas absolutas acerca de si el episodio de Dido y Eneas de la Eneida pudo influir de manera directa o indirecta (a través, por ejemplo, del romance de Por los bosques de Cartago) en el romance de La reina Ginebra y su sobrino que circuló por la España renacentista. En todos estos relatos, una reina que debe fidelidad a otro hombre (a su difunto esposo Siqueo en el caso de Dido y a su esposo Arturo en el caso de Ginebra) entablan una relación clandestina con un hombre de más baja condición (un refugiado en el caso de Eneas, un paje en el caso del sobrino de Ginebra), aprovechando la ocasión de una partida de caza en el bosque, de una tempestad violenta, de la separación inopinada de los acompañantes, de la necesidad imperiosa de encontrar refugio y calor. El texto de Virgilio -perfectísimamente conocido en la España del XVI-, majestuosamente trágico, procura pasar por alto los pormenores más concretamente eróticos; los textos de los dos romances españoles, de una picardía bastante explícita, se demoran precisamente en ellos, aunque los dejen envueltos en un manto de finísima sutileza. Y la situación -la de los amores que siguen al extravío en el bosque en mitad

\footnotetext{
${ }^{2}$ Fernando José Wolf y Conrado Hofmann, Primavera y Flor de Romances, o Colección de los más viejos y más populares romances castellanos, Berlín, Asher \& Company, 1856, núm. 110, vol. II, pp. 7-11.
} 
de la tormenta- es lo suficientemente general como para que podamos considerarla, también, un tópico literario de largo alcance, una especie de cronotopo que bajo su ancho arco podría albergar la escena virgiliana, los romances españoles y una pluralidad amplísima -a la que nos iremos asomando- de textos emparentados entre sí de manera difusa, ambigua, no necesariamente unidos por lazos genéticos unívocos y directos, aunque sí por un innegable y general aire de familia.

Adelantemos un simple y revelador ejemplo: la romántica Volkslied (Canción popular) op. 63, núm. 5, del poeta alemán Ferdinand Freiligrath (18101876), a la que puso música el gran Félix Mendelssohn-Bartholdy (18091847), que comienza así:
O säh' ich auf der Heide dort
Im Sturme dich, im Sturme dich!
Mit meinem Mantel vor dem Sturm
Beschützt' ich dich, beschützt' ich dich!
Und kommt mit seinem Sturme je
Dir Unglück nah, dir Unglück nah,
Dann wär dies Herz dein Zufluchtsort,
Gern teilt ich's ja, gern teilt ich's ja...
$¡ O h$, si te viera en la campiña
bajo la tormenta!
Con mi abrigo,
de la tormenta te protegería.
$\mathrm{Y}$ si se te acercara con su tormenta
la desgracia,
este corazón sería tu refugio.
¡Con qué placer lo compartiría...

Traigamos a colación también un ejemplo cinematográfico, entre los muchísimos que sería capaz el cine de proporcionarnos: En I confess (Yo confieso, 1953), la célebre película de Alfred Hitchcock basada en una novela de Paul Anthelme, la hermosa y rica esposa de un senador, Ruth Grandfort (papel interpretado por Anne Baxter), se reencuentra cuando regresa de la guerra con su primer amor, Michael Logan (al que encarna Montgomery Clift). Una cita en una isla apartada, una tormenta que se desencadena de repente, la necesidad de encontrar rápido refugio en una casita campestre, propician el

${ }^{3}$ Félix Mendelssohn Bartholdy, Sechs zweistimmige Lieder mit Begleitung des Pianoforte, núm. 5 (Volkslied). Tomo el texto alemán y la traducción española (de Josep Bernat Enguix, 2008), de la página web especializada www.kareol.es. 
reencuentro amoroso entre la rica propietaria y el recién llegado soldado. A partir de ahí, la trama discurre por derroteros hitchcockianos: él descubre que ella es una mujer casada, huye, se hace sacerdote y al cabo del tiempo ambos se ven envueltos en una turbia trama de asesinatos e intrigas.

Sea cual sea el grado - directo o indirecto-de parentesco entre los relatos de Dido y el romance de Ginebra, y entre ambos y la amplia y pluricultural familia de relatos acerca de amores entre damas ricas y varones desheredados sobre fondo de tormenta, no podemos demorar ya más el conocimiento del romance español. Aparece publicado en la Tercera Parte de la Silva de romances que vio la luz (en las prensas de Steuan G. de Nagera) en Zaragoza en 1551:

Caualga doña Ginebra de Cordoua la rica, con trezientos caualleros que van en su compañía. El tiempo haze tempestuoso, el cielo se escurescía, con la niebla que haze escura a todos perdido hauía, sino fuera a su sobrino, que de riendas la traýa; como no viera a ninguno, desta suerte le dezía:

- Toquedes vos, mi sobrino, vuestra dorada vozina, porque lo oyessen los míos, qu'estauan en la montiña.

-De tocalla, mi señora, de tocar sí tocaría, mas el frío haze grande, las manos se me elarían, y ellos están tan lexos que nada aprouecharía. - Meteldas vos, mi sobrino, so faldas de mi camisa.

-Esso tal no haré, señora, que haría descortesía, porque vengo yo muy frío y a vuestra merced elaría.

-Desso no cureys, señor, que yo me lo sufriría: quen callentar tales manos, qualquier cosa se çufría. Él, de que vio el aparejo, las sus manos le metía; pellizcárale en el muslo, y ella reýdo se hauía; apeáronse en vn valle que allí cerca parescía; solos estauan los dos, no tienen mas compañía: como veen el aparejo, mucho holgado se hauían ${ }^{4}$.

El romance de La reina Ginebra y su sobrino debió de tener alguna difusión en las décadas centrales del siglo Xvi, porque en el llamado Cancionero Manuscrito de Pedro del Pozo de 1547 figura anotada esta mucho más recatada versión, que se las ingenia como puede -con resultados no del todo logrados-para atenuar el erotismo que rezumaba la que debía ser rama dominante de versiones:

${ }^{4}$ Silva de romances (Zaragoza, 1550-1551), ed. Antonio Rodríguez-Moñino, Zaragoza, Publicaciones de la Cátedra Zaragoza del Ayuntamiento, 1970, p. 427. Regularizo la puntuación y la acentuación de acuerdo con la norma moderna. 
Leuantóse doña Ginebra un lunes antes del día; perdido auíe su gente con una mala neblina.

- Toquedes, sobrino, toquedes corneta de plata fina.

-De tocarla, mi señora, de tocarla, sí haría, mas los monteros [son] lexos, muy espesa es la montiña; las manos tengo eladas, y la boca tengo fría.

- Si las manos tenéis heladas, poneldas en mi camisa;

si fría tenéis la boca, ponelda con esta mía.

-De ponerla yo, señora, de ponerla, sí pondría, mas el diablo es sutil, y a entramos engañaría.

- Si el diablo es sutil y cres que te engañaría, el Padre Sancto está en Roma que a entramos perdonaria. - Jesu Christo está en el cielo, que nos lo demandaría ${ }^{5}$.

No conocemos ninguna versión más de este romance, aunque el hecho de que se haya documentado dos veces, en 1547 y en 1551, hace presumir que debió tener-como la gran mayoría de los romances acogidos en las compilaciones de por entonces-alguna difusión en la tradición oral de mediados del XVI.

En cuanto al hipotético parentesco de Por los bosques de Cartago y de La reina Ginebra y su sobrino, las coincidencias argumentales generales (la escenografía silvestre y tempestuosa y los detalles de la relación que entablan los personajes, similares a los de la Eneida de Virgilio) y las coincidencias argumentales específicas (la aparición del extraño «sobrino de la reina» y la ardorosa escena del manto o de las faldas encubridoras, que no aparecían en la Eneida) son lo suficientemente llamativas pero también lo bastante poco concluyentes como para que parezca aconsejable no pronunciarnos, de momento, acerca de su (¿genética o casual?) semejanza. Queden ahí apuntadas, y que cada lector se haga la opinión que quiera.

A Diego Catalán ${ }^{6}$, Giuseppe di Stefano ${ }^{7}$ y Pedro M. Piñero ${ }^{8}$ se deben comentarios o artículos indispensables acerca de las fuentes y de la poética de

\footnotetext{
${ }^{5}$ Antonio Rodríguez-Moñino, El Cancionero Manuscrito de Pedro del Pozo (1547), Madrid, Silverio Aguirre, 1950, pp. 88-89. Hago algunos cambios en la puntuación y en la acentuación de acuerdo con la norma moderna.

${ }^{6}$ Diego Catalán, «Lanzarote y el ciervo del pie blanco», Por campos del romancero. Estudios sobre la tradición oral moderna, Madrid, Gredos, 1970, pp. 82-100, pp. 85-86.

${ }^{7}$ Giuseppe Di Stefano, Romancero, Madrid, Taurus, 1993, pp. 158-159. Véase además el artículo de Di Stefano, «Romancero viejo y lírica tradicional: espigueos», en De la canción de amor medieval a las soleares. Profesor Manuel Alvar "in memoriam”, edición de Pedro M. Piñero, Sevilla, Universidad, 2004, pp. 101-114.

${ }^{8}$ Pedro M. Piñero, «De lo que aconteció a la reina doña Ginebra en el camino de Córdoba», Dejar hablar a los textos: Homenaje a Francisco Márquez Villanueva, ed. Pedro M. Piñero, 2 vols., Sevilla, Universidad, 2005, II, pp. 967-984.
} 
La reina Ginebra y su sobrino, por más que ninguno de ellos lo cotejase con el romance de Por los bosques de Cartago. En lo que básicamente vienen todos a coincidir es en que el romance ofrece un acercamiento sumamente original, de un erotismo muy sutil y refinado, al muy difundido motivo de los encuentros adulterinos de la reina Ginebra (la esposa del rey Arturo) y de Lanzarote, quien, si no era su sobrino, sí era cortesano muy allegado, casi familiar adoptivo, de la legendaria real pareja británica. Di Stefano apunta la posibilidad también de que el romance evoque la no menos adulterina relación (que aireó alguna fuente medieval) de Ginebra con Mordret, el hijo de Arturo. Y Piñero analiza (entre otras cuestiones) la densa simbología erótica que se halla condensada en sus entresijos, llamando la atención sobre algunas de sus metáforas menos inocentes: las del encuentro en «la montiña», la alusión a la equívoca bocina del varón, la acogida bajo las faldas femeninas...

Acerca del erotismo que destila el romance, según se manifiesta en lo que podríamos considerar metáforas y motivos líricos y narrativos diversos pero ensamblables, voy a explayarme yo también, aunque mirando hacia otros horizontes y trayendo a colación paralelos de cierta novedad.

Advertiré, a modo de preámbulo, que el tópico del perder (sobre todo el ganado) o del perderse en el campo, el monte o la sierra cumplen el papel de metáforas de la unión amorosa en versos y prosas de muchas épocas y culturas9.

A esto hay que añadir que el tópico de la dama de elevada condición que tiene o que intenta tener amores (insinuándose, seduciendo, requiriendo, imponiendo) con un hombre de condición baja o servil cuenta con una tradición muy firme y constante en el ámbito del romancero hispánico. De un modo o de otro, atañe a romances como los de Gerineldo, Blancaniña, La bastarda y el segador, La adúltera, Landarico, Bernal Francés, La Condesa traidora, El conde Alemán y la reina, La Gentil dama y el rústico pastor, El conde Alarcos, Raquel lastimosa, La adúltera y el cebollero... Algo no muy distinto se puede detectar en el ámbito del cuento tradicional y del cuento letrado, en el que varones de humilde condición y princesas a veces tímidas e inaccesibles, pero en otras ocasiones decididas y más que desenvueltas, forman también parejas relativamente típicas. Es preciso que no abramos ahora más frentes de los que tenemos ya abiertos, pero baste recordar, como muestra de la difusión del tópico, las repetidísimas escenas en que una reina o dama noble intenta seducir a algún servidor y, cuando es rechazada, le calumnia y acusa rencorosamente de violación. Motivo que arrastra desde la leyenda

\footnotetext{
${ }^{9}$ Véase al respecto José Manuel Pedrosa, «El buen pastor y el pastor descuidado, o la divina virtud frente al amor humano (de la hagiografía medieval al cine)», E-Humanista, 11 (2008) pp. 81-120. http://www.ehumanista.ucsb.edu/volumes/volume 11/Articles/4\%20Pedrosa.pdf
} 
bíblica de José y la mujer de Putifar, y que alcanzó una difusión enorme en toda la literatura europea medieval, incluida la caballeresca hispana.

Sobre las razones de la difusión apreciabilísima del tópico (que podríamos llamar, a grandes rasgos, de La dama seductora) en los territorios del romancero o del cuento tradicional haremos alguna reflexión adicional en un estudio futuro. Miraremos ahora hacia otros textos y hacia unas cuantas tradiciones menos obvias.

\section{«Quién m'aora'cá mi sayo»}

Cambiemos de género - pasando del romancero al cancionero-, pero sin movernos del siglo XVI. En su Triumpho do inverno (1529) hizo cantar Gil Vicente esta cancioncilla al rústico Brisco Pelayo, mientras se quejaba del frío y de la nieve que le tenían aterido:

¿Quién m'aora'cá mi sayo,

cuytado!

¡Quién m'aora'cá mi sayo!

El moço y la moça

van en romería,

tómales la noche

' $\mathrm{n}$ aquella montina.

¡Cuytado!

¿Quién m'aora'cá mi sayo!

Tómales la noche

'n aquella montina;

la moça cantava,

el moço dezía:

"iCuytado!

¡Quién m'aora'cá mi sayo!»

Además, en el Auto dos quatro tempos, del mismo Gil Vicente, otro personaje ponía en relación los sones de la cancioncilla con las inclemencias del tiempo invernal: «Quiérome echar a dormir, ver si puedo callentar... ¡Oh, quién mora ca mi sayo para cobrirme estos pies!» ${ }^{10}$.

Margit Frenk, en un estudio que tiene ya la categoría de clásico ${ }^{11}$, ha

${ }^{10}$ Véase, sobre las versiones antiguas de la canción, Margit Frenk, Nuevo corpus de la antigua lírica popular hispánica (siglos XV a XVII), México D.F., Fondo de Cultura Económica, 2003, núm. 6.

${ }^{11}$ Frenk, «Quién maora ca mi sayo», Poesía popular hispánica: 44 estudios, México D.F., Fondo de 
llamado la atención sobre los símbolos eróticos que se dan cita en esta cancioncilla cuya interpretación se ve dificultada por obstáculos prácticamente insalvables: en primer lugar, porque su documentación antigua es sumamente escueta, pues se ciñe a los textos gilvicentinos que acabamos de conocer; después, porque se trata de testimonios incompletos, truncados -de acuerdo con una moda que era común en las ediciones de poesía erótica de la épocacuando la escena comenzaba a coger temperatura y los hechos parecía que estaban a punto de precipitarse; y, además, porque su lenguaje y su sentido parecen afectados por procesos de corrupción o de erosión -y quizás también por anomalías de tipo dialectal, concretados en la enigmática voz m'aora'cáque dificultan gravemente la comprensión por parte del receptor de hoy, $\mathrm{y}$ puede que también por la del receptor del siglo XVI.

Pese a todas estas sombras, es obvio que algún suceso interesante debió acontecer a partir del momento en que se les hizo de noche en mitad del monte a aquel mozo y aquella moza que habían salido juntos de romería. Algún suceso en que el sayo del mozo, tantas veces invocado, tenía por fuerza que desempeñar un papel central, y que impelió al varón a declararse cuytado en medio de aquella situación. Con más ironía que sinceridad, posiblemente, porque -recuérdese- también el sobrino de la reina Ginebra, perdido con su tía en lo más espeso del monte, se declaraba -cínicamente- preocupado por que el sonido de su bocina no fuese a ser escuchado -ni falta que hacía, ni ganas que tenía- desde lejos, o porque la frialdad de sus manos pudiese derivar en descortés molestia para su reina. «No es imposible que, en nuestro cantar, al clamar por un sayo el mozo dé expresión a un deseo más profundo y menos prosaico», de índole claramente erótica, que el de sacudirse simplemente el frío, señala al respecto la profesora Frenk: «Nuestra frase no sería entonces una lamentación, sino una gozosa y pícara exclamación, y el ;cuitado! sería tan fingidamente patético como el mezquina del cantar So ell encina» ${ }^{12}$. (So ell encina será la canción que analizaremos a continuación de ésta).

En esa irónica picardía que ha sabido detectar Margit Frenk se halla, a buen seguro, la clave ideológica de Quién m'aora'cá mi sayo y de So ell encina. El cotejo añadido con el romance de La reina Ginebra y su sobrino, en que tiene un papel central el refugio bajo las faldas de la reina como estrategia no tanto para aliviar el frío como para la comunión amorosa, y en que se hallan presentes las cínicas, fingidas y reiteradas reticencias puestas en boca del mozo -que la mujer se ocupa desenvueltamente de despejar en los versos finales-avala, sin duda, esta interpretación.

Cultura Económica, 2006, pp. 643-649.

${ }^{12}$ Frenk, «Quién maora ca mi sayo», pp. 648-649. 
Lo que resulta indiscutible es, en cualquier caso, que con los ingredientes de la canción Quién m'aora 'cá mi sayo -la romería, el monte, la noche, el frío, el mozo, la moza y el sayo- lo único que se podía cocinar era un guiso erótico en que al sayo le estaría reservado, con seguridad, el papel de tapadera.

\section{«So ell enzina, enzina»}

Es evidente que la canción de Quién m'aora'cá mi sayo se halla atravesada de un sutil pero inconfundible erotismo. Téngase en cuenta que los escenarios de la romería ${ }^{13}$ y de la montina que cita la canción figuraban entre los loca amoena favoritos de la lírica erótica de la época. Recordemos, al respecto, estos versos que el Cancionero musical de Palacio había atestiguado en los primeros años de aquel mismo siglo XvI, y que nos muestran la consumación del amor entre la romera y el mozo que se encuentran de noche en la montiña:

So ell enzina, enzina, so ell enzina.

Yo me iva, mi madre, a la romería, por ir más devota, fuy sin compañía. So ell enzina.

Por ir más devota, fuy sin compañía; tomé otro camino, dexé el que tenía. [So ell enzina].

[Tomé otro camino, dexé el que tenía], halléme perdida en una montiña. [So ell enzina].

\footnotetext{
${ }^{13}$ Sobre las resonancias eróticas de la expedición de jóvenes a la romería, véase Magdalena Altamirano, «El viaje a la romería en la antigua lírica popular hispánica: a propósito del romance-villancico Ventura sin alegría», La Corónica, 37 (2009), pp. 133-156, y la bibliografía que cita.
} 
[Halléme perdida en una montiña], echéme a dormir al pie d'ell enzina. [So ell enzina].

[Echéme a dormir al pie d'ell enzina]; a la media noche recordé, mezquina. [So ell enzina].

[A la media noche recordé, mezquina], halléme en los braços del que más quería. [So ell enzina].

[Halléme en los braços del que más quería]: pesóme, cuytada, desque amanecía. [So ell enzina].

[Pesóme, cuytada, desque amanecía], porque ya goçaba del que más quería. [So ell enzina].

[Porque ya goçaba del que más quería]: ¡muy bendita sía la tal rromería! [So ell enzina $]^{14}$.

\section{«Y no parezca nadie en la montiña»}

Los amoríos de esta canción no quedan consumados debajo de ninguna camisa ni de ningún sayo cómplices, pero sí a la sombra de uno de esos ár-

${ }^{14}$ Frenk, Nuevo corpus, núm. 313. 
boles que cumplen, en las tradiciones literarias de tantas épocas y lugares, el papel de encubridores de galanteos y de juegos eróticos ${ }^{15}$. Recuérdese el antecedente viejísimo e ilustre de la célebre canción Under der linden (Bajo el tilo) del trovador alemán Walther von der Vogelweide (ca. 1170ca. 1228):

I

Bajo el tilo,

en el campo,

allí donde estuvo nuestro lecho,

podréis encontrar

con gracia,

rotas las flores y la hierba.

En un valle, junto al bosque,

tandaradei

cantaba, bello, el ruiseñor.

II

Fui andando

a la pradera

y ya estaba allí mi amor.

Allí fue recibida

como gentil dama,

por lo que estaré siempre contenta.

¿Me besó? ¡Más de mil veces!

Tandaradei,

mirad cómo tengo de roja la boca.

III

Él había hecho allí

un lecho

muy rico, de flores.

Aún sonreirá

de corazón

quien vaya por aquel sendero:

entre las rosas,

tandaradei,

reconocerá dónde apoyaba yo la cabeza.

\footnotetext{
${ }^{15}$ Véase al respecto Pedro M. Piñero, «Lorca y la canción popular. Las tres hojas: de la tradición al surrealismo», La niña y el mar: formas, temas y motivos tradicionales en el cancionero popular hispánico, Madrid, Iberoamericana-Vervuert, 2010, pp. 583-634.
} 
IV

Lo que hizo conmigo, si lo supiera alguien (¡no quiera Dios!), me avergonzaría. ¿Cuál fue su comportamiento conmigo nadie lo sabe, sino él y yo y un pajarillo; tandaradei, fielmente nos guardará el secreto ${ }^{16}$.

Y téngase en cuenta también la preciosa canción folclórica asturiana, que combina la acción protectora del árbol con la de la «mantillina»:
Con los tus manteles
y la mi anguarina
vamos a la sombra
de la verde oliva,
y por cabecera
la tu mantillina ${ }^{17}$.

Pero, además, los escarceos de So ell enzina, enzina se producen también sobre el escenario de una emblemática montiña, como aquella que evocaba San Juan de la Cruz en la canción 16 del Cántico espiritual:
Caçadnos las raposas, questá ya florescida nuestra viña, en tanto que de rosas hazemos una piña, y no parezca nadie en la montiña ${ }^{18}$.

Crucial para nosotros este verso de San Juan de la Cruz, «y no parezca nadie en la montiña», porque podría ser suscrito, palabra por palabra, por los entusiasmados (aunque se declaren hipócritamente cuytados) amantes perdidos en la espesura de La reina Ginebra y su paje, o de Quién m'aora'cá mi sayo, o de So ell enzina, enzina, y porque nos confirma una de las claves sin duda indispensables para entender todos estos poemas: el extravío de los

\footnotetext{
${ }^{16}$ Carlos Alvar, Poesía de trovadores, trouvères y Minnesinger (edición bilingüe), Madrid, Alianza, reed. 1999, pp. 348-351.

${ }^{17}$ Martínez Torner, Cancionero musical de la lírica popular asturiana, Madrid, Nieto y compañía, 1920, núm. 8.

${ }^{18}$ San Juan de la Cruz, Poesía, ed. Domingo Ynduráin, Madrid, Cátedra, 1993, p. 252.
} 
dos jóvenes en la sierra, en el monte, en la montiña, es un extravío deseado, consumado a propósito; las cuytas que suscita en ellos son cuytas fingidas, cínicas tapaderas (igual que la camisa, lo mismo que el sayo) del encuentro y de la explosión de hasta entonces reprimido gozo amoroso.

Por cierto, que sobre las connotaciones tópicamente eróticas de estas sugerentes montiñas se expresó de este modo, dando vueltas a los versos de San Juan de la Cruz, Jorge Guillén:

A los grandes espacios de recogimiento y soledad con montañas, valles, ínsulas, ríos suceden pinturas de ligereza matutina y sonriente: guirnaldas de flores, flores entretejidas a cabellos, frescas mañanas, piñas de rosas. La 'montaña' se convierte en 'montiña', y no sólo por exigencia del juego rimado. Todo es amor: «que ya sólo en amar es mi ejercicio» ${ }^{19}$.

\section{«Asomada de una montiña»}

Tenía toda la razón Jorge Guillén: tan estrecha vinculación con el amor («todo es amor») tenía esta paradigmática montiña que, en una versión del siglo XVI del romance de La infantina y el caballero burlado, cuando estaba apenas rescatada del bosque («á la salida de un monte / y asomada de una montiña»), se reía la joven traviesamente del caballero porque, pese a algunos vacilantes y al final frustrados intentos de acercamiento, éste «tenía niña en el monte, / y usaba de cortesía», dejando sin consumar el acto amoroso. A lo que el varón, como cayendo de repente en la cuenta de lo antinatural (y algo vergonzoso) de la situación, respondía intentando volver sobre sus pasos, con el fin de someterse a sí mismo y a ella al casi inapelable guión, tantas veces escrito y tantas veces interpretado (en la realidad y en la literatura), de los amores en la montiña:

De Francia partió la niña, de Francia la bien guarnida, perdido lleva el camino, perdida la lleva la guía, arrimárase a un roble por atender compañía, vido venir un cavallero, dispuesto a maravilla, comiénçale de fablar, tales palabras dezía:

«¿Qué hazéis aquí, mi alma? ¿Qué hazéis aquí, mi vida?».

Allí fabló la donzella, bien oiréis lo que dezía:

«Espero compañía, señor, que a París llevo mi guía».

Respondiole el cavallero, tales palabras dezía:

«Si te pluguiesse, señora, comigo te llevaría,

${ }^{19}$ Jorge Guillén, Lenguaje y poesía. Algunos casos españoles, Madrid, Alianza, reed. 1992, p. 80. 
si quieres por muger o si quieres por amiga».

La niña, qu'estava sola, estas palabras dezía:

«Plázeme-dixo-, señor, plázeme-dixo-, mi vida,

si vós me dades la mano, yo luego cavalgaría».

El cavallero le da la mano, la niña presto subía, andando por su camino, de amores la requería.

Ay' habló la donzella, bien oirés lo que dezía:

«Estad quedo, el cavallero, no fagáis tal villanía, que fija soy de un malato que tiene la malatía, que quien a mí llegare, luego se le pegaría, que si vós a mí llegades, la vida vos costaría, mucho vos ruego, señor, que me catéis cortesía».

$\mathrm{Y}$ a la salida de un monte e assomada de una ermita, el cavallero iva seguro, la niña se sonrreía.

Ay' fabló el cavallero, bien oiréis lo que dezía:

«¿De qué vos reís, mi alma? ¿De qué vos reís, mi vida?».

La niña, que estava en salvo, aquesto le respondía:

«Ríome del cavallero y de su gran cobardía,

que tenía la niña en el monte y usava de cortesía».

Desqu'esto oyó el caballero, él ahorcar se quería, con gran enojo que tiene, estas palabras dezía:

«Cavallero que tal pierde, grande pena merecía,

él mesmo se es el alcalde, él mesmo se es justicia,

que le corten pies e manos e lo cuelguen de una enzina».

$Y$ él en esto estando y que hazer lo quería,

si no fuera por una fada que a fablar le venía,

las palabras que le dize, quienquiera se las sabía:

«No desesperes, cavallero, no desesperes de tu vida,

darte ha Dios gran vitoria en arte de cavallería,

que con los vivos se sirve Dios y su madre Santa María ${ }^{20}$.

En un artículo futuro exploraré más montañas y montiñas típicamente amorosas. Adelanto ahora solo estos preciosos y sugestivos versos asturianos, que advierten contra tales (y tan tópicos) amores:

— ¿Dónde vas de madrugada,

prenda querida,

tando la nieve cuayada

por la campiña?

\footnotetext{
${ }^{20}$ Laura Puerto Moro, Obra conocida de Rodrigo de Reinosa, San Millán de la Cogolla, Cilengua, 2010, pp. 287-290.
} 
—¿Dónde voy de madrugada, triste de mí!:

a buscar la paz del alma

que acá perdí.

- Si a buscar nuevos amores

vas a acullá,

de pena, ramín de flores,

muero yo acá.

—Desque vine a tierres baxes

non puedo tar

tranquila y asosegada

y en $\sin$ llorar.

—Ven acá, prenda adorada, non subas a la montaña, la nieve te cubrirá.

—Tú enamores otres moces sin cumplir aquelles coses que me xuraste al baxar.

-Non llores, ramín de roses, que pa' mí les otres moces u tas tú non valen ná ${ }^{1}$.

Añado también estos versos nicaragüenses, que no precisan de mayor comentario:

$$
\begin{aligned}
& \text { Mi linda, vamos al monte, } \\
& \text { y a'i te perderás conmigo; } \\
& \text { si sos la cusuca vos, } \\
& \text { yo seré tu cusuquito }{ }^{22} \text {. }
\end{aligned}
$$

\section{«Metedle bajo la saya, si queréis que calor cobre»}

En alguna monografía futura seguiremos transitando por una pintoresca geografía de montes, montiñas, selvas y bosques amorosos. Adelantemos

\footnotetext{
${ }^{21}$ Martínez Torner, Cancionero musical de la lírica popular, núm. 497.

${ }^{22}$ Canción registrada por mí en enero de 2010 en León, Nicaragua. El informante fue I. Rodríguez Silva.
} 
ahora estos muy sugestivos versos de muiñeira gallega, que integran en una muy interesante ecuación el monte, el frío y la calentura erótica:

Cando te vexo n-a eira d'o río, queda ó meu corpo tembrando de frio; cando te vexo d'o monte n'altura á todo ó meu corpo lle da calentura ${ }^{23}$.

Retornemos, ahora, a las faldas, a la camisa, al sayo que ofrecían calor a los amantes deseosos de intimidad. Y conozcamos, para empezar, las faldas cantadas en los versos que armonizó Luis de Milán en el Xvı:
¡Agora viniesse un viento
que me echasse acullá dentro!
Agora viniesse un viento
tan bueno como querría,
que me echasse acullá dentro,
en faldas de mi amiga,
y me hiciesse tan contento,
que me echasse acullá dentro ${ }^{24}$.

Nos asomaremos a continuación a una joya del cancionero tradicional portugués que se nos muestra como una especie de apología de la prenda encubridora (un gabán o abrigo, en este caso) de amores de romería. Matiz, éste de la romería, crucial para nuestro análisis, después de tantos amores romeros como han pasado ya ante nuestros ojos:
O gabão do meu avó que me veio de herança
Tantas vezes me tapou cuando ia comigo a Querença.
Em dia de Romaria me Ievava p'la mão era quando me cobria com o capuz do gabão.

\footnotetext{
${ }^{23}$ José Casal Lois, Colección de cantares gallegos, ed. Domingo Blanco, Santiago de Compostela, Consello da Cultura Galega-Museo de Pontevedra, 2000, p. 311.

${ }^{24}$ Luis de Milán, Libro de música, núm. 31. Cfr. Frenk, Nuevo corpus, núm. 255.
} 
Com carinhos e afectos

Deus lhe dê protecção

para cobrir os meus notos

ficou para mim o gabão ${ }^{25}$.

Volvamos ahora a la tradición áurea española. Primero, a unos cuantos versos de un hermosísimo poema de la Flor d'enamorats (1573) de Timoneda en que el amante, sin duda muy desquiciado, expresa el deseo de convertirse en 'lo cobertor' mismo de su señora:

Puix sou, senyora, la caixa

on està lo meu tresor,

io que fos lo cobertor.

Ai!, quant bé que us cobriria

sense puntet discrepar!

No hi ha qui ho sàpia contar,

de la gràcia que ho faria;

en tota honra i cortesia,

sent la caixa del tresor,

io que fos lo cobertor ${ }^{26}$.

Es el turno, ahora, de unos versos que extracto de un villancico glosado anónimamente hacia 1620 sobre el que no hace falta decir más que vuelve a estar puesto en boca de un varón 'pobre' que implora a una 'señora' que «me deis, / en que envuelva un niño mío, / que se me muere de frío / y a ratos se me desmaya. / Metedle bajo la saya, / si queréis que calor cobre...». Huelga, seguramente, cualquier comentario:

¿Si hay quien dé limosna a un pobre, si hay quien dé limosna a un pobre, que, si no lo masca, no lo come?

Señora, dadme un poquito deso que tenéis guardado, a un pobre que no ha almorzado, no por falta de apetito,

\footnotetext{
${ }^{25}$ Fátima Rosado, coord., Tradição oral algarvia I Poesia recolhida na freguesia de Querença, Faro, Universidade, 1993, p. 137.

${ }^{26}$ Joan Timoneda, Flor d'enamorats, introducció de Joan Fuster, Valencia, Clàssics Albatros, 1973, núm. 25.
} 


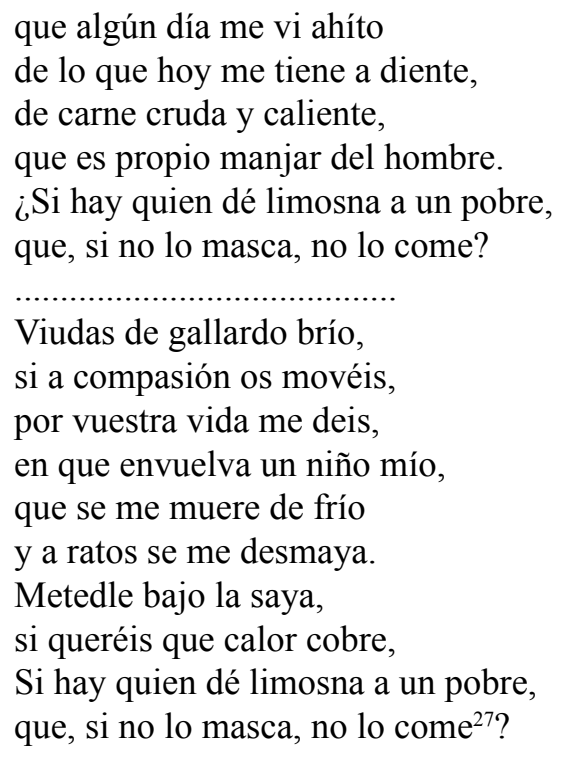

\section{«Tápame, tápame, tápame»}

Margit Frenk, en el estudio que ya hemos citado acerca de Quién m 'aora 'cá $m i$ sayo, ha traído a colación unas cuantas canciones tradicionales modernas, tan sugerentes como reveladoras, que parecen avalar la posibilidad - una entre las varias que evalúa la profesora mexicana- de que Quién m 'aora'cá mi sayo exprese una queja (irónica, incluso cínica) contra el frío del monte, y, sobre todo, una excusa para el acercamiento carnal de los amantes bajo el abrigo de la prenda de vestir. Esta canción señalada por la profesora Frenk fue registrada en Asturias. Como más adelante veremos, es un fragmento de un cuplé que acabó relativamente folclorizado:

-Tápame, tápame, tápame, tápame que tengo frío.

— ¿Cómo quieres que te tape, si yo no soy tu marido? ${ }^{28}$.

Estos otros versos de los señalados por la profesora Frenk tienen gran arraigo en la tradición oral mexicana, hasta el punto de que algunos han llegado a sonar en voces tan célebres como la de Chavela Vargas. Muchos («mira

\footnotetext{
${ }^{27}$ Tomado del manuscrito Poesías diversas. BNM Ms. 3.985, según la edición de Pierre Alzieu, Robert Jammes e Yvan Lissorgues, Poesía erótica del Siglo de Oro, Barcelona, Crítica, 1984, núm. 96.

${ }^{28}$ Martínez Torner, Cancionero musical de la lírica popular, núm. 223.
} 
qué tormenta viene / si no me tapas, me mojo...») resultan extraordinariamente sugerentes y valiosos para nuestro análisis:

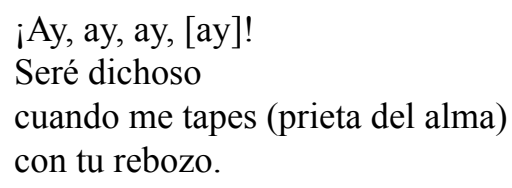

¡Ay de mí, Llorona, Llorona, llévame al río, tápame con tu rebozo (Llorona), porque me muero de frío.

Yo soy un gavilancillo que ando por aquí en el río; cobíjame con tus alas, que ya me muero de frío.

-Paloma, ¿de dónde vienes?

- Vengo de San Juan del Río.

-Cobíjame con tus alas, que ya me muero de frío.

—Paloma, ¿de dónde vienes?

- Vengo de San Juan del Río.

-Cobíjame con tus alas, porque me muero de frío.

- Te abrigaré con mis alas, pobre pichoncito mío, mas vámonos luego, luego, para mi San Juan del Río.

Mariquita se llamaba la que vive junto al río; tápame con tu rebozo, que ya me muero de frío.

Cuando te vayas al pozo con tu cántaro vacío, tápame con tu rebozo, porque me muero de frío.

Si no me quieres, me enojo, 
mira qué tormenta viene (güerita):

si no me tapas, me mojo.

¡Ay, no quiero, no quiero, no quiero

la sombra de tu rebozo;

solo tu sombrita quiero,

pero saliendo del pozo.

¡Ay!, no quiero, no quiero, no quiero

la sombra de tu reguajo;

solo tu samista quiero (sic?)

pero saliendo del bajo.

Señora, si usted quisiera

hacerme una caridad, partiera su rebocito

ahí me diera la mitad,

para hacerme un cotoncito

que ya vergüenza me $\mathrm{da}^{29}$.

\section{«No me toquéis... que tenéis las manos frías»}

En el llamado Cancionero de Gabriel de Peralta (Manuscrito 4072 de la Biblioteca Nacional de Madrid), de hacia 1600, se halla anotada -incompleta, una vez más- esta otra canción:

¡Quedito, no me toquéis,

entrañas mías,

que tenéis las manos frías!

Yo os doy mi fe que venís

esta noche tan helado,

que si vos no lo sentís

de sentido estáis privado.

No toquéis en lo vedado,

entrañas mías,

que tenéis las manos frías ${ }^{30}$.

${ }^{29}$ Margit Frenk y otros, Cancionero folklórico de México, 5 vols., México, El Colegio de México, 1975-1985, núms. 1438-1447. Añádase esta otra versión, editada en Celedonio Serrano Martínez, Coplas populares de Guerrero, Toluca, Testimonios de Atlacomulco, 1972, p. 67: «Ay! Soledad, Soledad, / vamos al río; / tápame con tu rebozo / que ya me muero de frío!».

${ }^{30}$ La canción se halla editada en José María Alín, Cancionero tradicional, Madrid, Castalia, 1991, núm. 681. Los versos de cabeza están en Frenk, Nuevo corpus, núm. 1687. 
Una canción más protagonizada por un amante con las manos frías y por una dama que protesta, cínicamente, por un acoso amoroso que ella desea, bien se ve, tanto como él. Y otra interrupción estratégica cuando el asunto, apenas sugerido, empieza a ponerse interesante. Se aprecia muy bien, en cualquier caso, que de nuevo se intenta hacer pasar la desenvoltura por indefensión, el ardor por ingenuidad, el deseo amoroso por escrúpulo fingido y cínico recato. Como posiblemente sucede también en estas seguidillas de comienzos del XVII:
No me llegue al manto, que me destoca:
que me tiene mi madre para ser monja.
No me tire del manto, que soy doncella, que mi madre me guarda para conserva ${ }^{31}$.

Más adelante tendremos ocasión del examinar más canciones, vivas en la tradición oral moderna, que se articulan, a nivel de detalle (o de metáforamotivo) y a nivel de estructura (o de tipo), sobre los mismos tópicos. Adelantaremos aquí solo unos versos folclóricos que tienen el mérito de concordar a veces literalmente («que tienes las manos frías...», «ea, que tengo frío...») con los que acabamos de conocer:

Tú te vas, tú te vienes, yo no te llamo.

Como paso el invierno, paso el verano.

Paso el verano, niña, paso el verano.

Tú te vas, tú te vienes, yo no te llamo.
A la subida de El Cerro se oyó una voz que decía:
-Estate quieto, Manolo, que tienes las manos frías.
- Si tengo las manos frías,

\footnotetext{
${ }^{31}$ Estrofas tomadas del Ms. 3985 de la BNM. Véase Frenk, Nuevo corpus, núm. 1686.
} 


$$
\begin{aligned}
& \text { déjalas que se calienten. } \\
& \text { —Estate quieto, Manolo, } \\
& \text { que está mirando la gente. } \\
& \text { ¡Qué contento me pongo } \\
& \text { cuando la riegan } \\
& \text { con la manga de riego } \\
& \text { la carretera! } \\
& \text { La carretera, niña, } \\
& \text { la carretera, } \\
& \text { iqué contento me pongo } \\
& \text { cuando la riegan }{ }^{32 !} \\
& \text { Cojo, recojo, } \\
& \text { cojito mío, } \\
& \text { tápame con tu manto, } \\
& \text { ea, que tengo frío }{ }^{33} \text {. }
\end{aligned}
$$

Antes de seguir desgranando más paralelos es preciso que nos entretengamos en explorar algunos terrenos aledaños.

\section{La diosa a quien sacrifica}

Atribuido (con muchísima probabilidad) a Lope de Vega, aunque nunca fuera acogido en las publicaciones que el propio poeta preparó o autorizó en vida, se halla documentado a finales del siglo XVI y a comienzos del XVII un romance artificioso que tiene cierto interés, sobre todo en su desenlace, para nosotros. Muestra, en efecto, a la diosa Venus que va en busca de su hijo Amor, extraviado no se sabe dónde. Lo encuentra, al cabo de mucho peregrinar (la composición se ajusta así al viejo molde narrativo de las peregrinaciones por el mundo de la diosa Deméter en busca de su hija Perséfone), en una choza pastoril que se halla en «una sierra... cubierta de niebe», «temblando de frío y de ambre, / calentándose las manos / a unas llamas que salen / del pecho de un pastorcillo / que sobre unas pieles yace...». La atribución lopesca se apoya, sin duda, en el seudónimo de Belardo que figura en el verso penúltimo, que Lope usó una y otra vez por la época de sus atormentados amores con Elena Osorio.

Reproduzco solo los versos iniciales y finales del extenso romance:

${ }^{32}$ Félix Contreras, Alejandro González y María Angustias Nuevo, Equipo de La Memoria Sumergida, Cancionero y romancero del Campo Arañuelo, Navalmoral de la Mata, Arjabor, 2006.

${ }^{33}$ Sixto Córdova y Oña, Cancionero popular de la provincia de Santander, 4 vols., Santander, Aldús, 1948-1949; reed. G. de Córdova, 1980, II, p. 160. 

La diosa a quien sacrifica
Samo y Cipro en mill altares, va buscando, peregrina, del mundo las quatro partes pa hallar al niño Amor, que ha días que dél no save,
Viendo aquesto Venus, fuese por una sierra adelante, adonde cubierta de niebe vio una choza de zagales. Entró dentro y vio [a] Cupido temblando de frío y de ambre, calentándose las manos a unas llamas que salen del pecho de un pastorcillo que sobre unas pieles yace, cuyo nombre era Belardo, solo verdadero amante ${ }^{34}$.

Los versos, seguramente de Lope, acerca del mismísimo dios Amor perdido en «una sierra... cubierta de niebe», «temblando de frío y de ambre, / calentándose las manos» al fuego del pecho enamorado de un pastorcillo no dejan de tener un sugerente aunque parcial (y posiblemente irónico) parecido con los que nos hablaban del paje perdido en una montiña tempestuosa que acaba aliviando sus manos al calor del cuerpo de la fogosa reina Ginebra; o con los de la canción de So ell encina (por citar una sola entre las muchas que estamos trayendo a colación) en que la moza se pierde en el monte oscuro antes de encontrarse en el regazo protector de su galán.

Lo que parece apuntar este romance presumiblemente lopesco es que el perderse en sierras y montes tempestuosos, fríos o nocturnos, y el buscar alivio a las manos heladas sobre el cuerpo de amantes o de amadores debió de ser tópico favorecido por una cierta tradición que admitiría, también, alguna apertura en la elección de peripecias y desenlaces, si el poeta era (como es el caso) lo suficientemente hábil e ingenioso. No nos enfrenta La diosa a quien sacrifica a la archisabida escena del varón y de la mujer extraviados en el monte, perseguidos por la tormenta y precisados de hallar calor el uno junto al otro. Pero sí nos relata el caso del varón extraviado en el monte, per-

\footnotetext{
${ }^{34}$ José J. Labrador Herraiz, Ralph A. DiFranco y Lori A. Bernand, Romancero de Palacio (siglo XVI), Cleveland, Cancioneros castellanos, 1999, núm. 32, pp. 36-37 y 330.
} 
seguido por la tormenta y obligado a hallar calor acercando sus manos a las llamas que salen exageradamente del pecho del solitario Belardo (¿Lope?) enamorado. Hipérbole manierista, ironía atravesada de amargura, que suman sus fuerzas en un cuadro barroco que tiene todos los visos de ser guiño sutil y parodia desengañada e infeliz de las harto conocidas escenas con mujer, varón, tormenta y feliz unión amorosa.

\section{«Debajo de la pompa / de tu camisa...»}

Muchas más canciones, aparte de las que ya vimos que había allegado la profesora Frenk, avalan la difusión del tópico poético del varón que busca refugio bajo las vestiduras de la mujer para no solo escapar de los rigores del frío o del invierno, sino también para conseguir alguna cosa (erótica) más.

El tópico de los amantes que se cubren bajo un mismo manto amoroso para protegerse del crudo invierno o del alba destemplada es viejísimo. Abunda, por ejemplo, en la tradición grecolatina, según ejemplifican estos dos breves poemas, de Asclepíades (siglos II-I a. C.) y Meleagro (siglo i a. C.), que se hallan incluidos en la Antología Palatina:

Dulce bebida en verano para el sediento es la nieve, dulce es para los marinos al salir del invierno ver la Corona primaveral, pero más dulce es cuando un solo manto cubre a los amantes y Cipris es honrada por ambos.

Alba, contraria a los amantes, ¿por qué ahora despacio giras alrededor del mundo, cuando otro se calienta bajo el manto de Demo? Cuando yo abrazaba tu esbelto cuerpo, rápida te presentaste y arrojaste sobre mí la envidiosa luz ${ }^{35}$.

Fue tópico también comúnmente medieval, de acuerdo con lo que atestiguan estos versos ( «Ab la dolchor del temps novel...») del primer trovador provenzal, Gilhem de Peitieu (finales del siglo XI-comienzos del XII), de matices tan sugestivos («poner bajo su manto mis manos...») si se comparan con los del romance español de La reina Ginebra y su sobrino ( «Meteldas vos, mi sobrino, / so faldas de mi camisa...»):

\section{III}

A nuestro amor le ocurre como a la rama del espino blanco que tiembla en el árbol

\footnotetext{
${ }^{35}$ Epigramas eróticos griegos: Antología Palatina (Libros Vy XII), trads. Guillermo Galán Vioque y Miguel Á. Márquez Guerrero, Madrid, Alianza, 2001, núm. 173, p. 92 y núm. 169, p. 91.
} 
por la noche, con la lluvia y el hielo

hasta que amanece, cuando el sol se extiende

por las hojas verdes, en la rama.

IV

Aún recuerdo una mañana

en que pusimos fin a la guerra

y me hizo un gran regalo:

su amor y su anillo.

¡Que Dios me deje vivir tanto

como para poner bajo su manto mis manos ${ }^{36}$ !

Reveladores son también los versos («Doutz brais e critz...») del trovador provenzal Arnaut Daniel, escritos a finales del siglo XII o en los inicios del XIII:

... el día que mi dama y yo nos besamos

y me hizo escudo con su bello manto azul

así que los falsos maldicientes, lengua viperina,

que difunden tan malas palabras no lo vieron ${ }^{37}$.

Igual de sugerentes son las palabras de otro poema («Can lo glatz e 1 frechs e la neus...») del trovador provenzal, Giraut de Bornelh (siglos XII-XIII):

Juglar, con estas nuevas melodías

vete y las llevarás personalmente

a la bella, en la que nace riqueza

y dile que soy más suyo que su manto ${ }^{38}$.

Es tópico, además, muy persistente. Fijémonos en el modo casi obsesivo en que esta desenvuelta canción que fue recogida en la provincia de Ávila insiste cínicamente en la excusa invernal:
Debajo de la pompa
de tu camisa
pasaré yo el invierno
muerto de risa.
Debajo de la pompa
de tus enaguas

${ }^{36}$ Alvar, Poesía de trovadores, trouvères y Minnesinger, pp. 82-85.
${ }^{37}$ Alvar, Poesía de trovadores, trouvères y Minnesinger, p. 165.
${ }^{38}$ Alvar, Poesía de trovadores, trouvères y Minnesinger, p p. 136-141. 
pasaré yo el invierno

aunque nevara.

Debajo de la pompa

de tu refajo

pasaré yo el invierno

y el mes de marzo.

Debajo de la pompa

de tu mandil

pasaré yo el invierno

y el mes de abril ${ }^{39}$.

Atendamos, también, a estas otras canciones, registradas en lugares y en tradiciones bien diversos, que dan vueltas y más vueltas sobre tópicos conexos:

Qué buena noche que está

para ir a la arboleda

tápame con tu capote

que mi mantilla no llega ${ }^{40}$.

No te acuerdas, Nicanora,

cuando debajo del puente

tú decías suspirando:

—Tápame, que viene gente ${ }^{41}$.

Algún día los aires

de la tu capa

me sirvieron de alivio,

$\mathrm{y}$ ahora me matan ${ }^{42}$.

Tápame con tu mantón, arróllame como a un niño,

\footnotetext{
${ }^{39}$ Kurt Schindler, Folk music and poetry of Spain and Portugal, Nueva York, Hispanic Institute, 1941, p. 8.

${ }^{40}$ Juan Carlos Martínez Fernández y Elena González-Blanco García, Formas de vida cultural y tradición oral en la cabecera riojana del Cidacos, recogidas desde El Villar de Poyales, en prensa.

${ }^{41}$ Félix Barroso Gutiérrez, «Viaje al pueblo hurdano de Asegur», Revista de Folklore, 134 (1992) pp. 64-69, p. 66.

${ }^{42}$ César Morán Bardón, «Poesía popular salmantina. Folklore», Obra etnográfica y otros escritos, 2 vols., Salamanca, Centro de Cultura Tradicional-Diputación de Salamanca, 1990, vol. I, pp. 39-100, p. 100 .
} 
que se me murió mi madre

y ando falto de cariño ${ }^{43}$.

Otras veces mi capote

andaba en el contrabando,

arropándote de noche,

$\mathrm{y}$ ahora me preguntas cuándo ${ }^{44}$.

En la tradición gallega han abundado las canciones de amores cubiertos y encubiertos:

\author{
O Cura de San Vicente \\ evos un gran confesor \\ que confesa â sua criada \\ debaixo d'ó cobertor. \\ Heiche de dar catro cartos \\ é mais un chavo rabelo \\ si me deixas abrigar \\ debaixo d'o teu mantelo. \\ Hay moito liño iste ano \\ é ha d'haber moita aresta; \\ debaixo d'a tua saya... \\ eso é ó qu'á min me presta ${ }^{45}$.
}

Una muy ingeniosa adivinanza manchega (la solución, un tanto decepcionante, es 'la lavativa') viene a poner un broche más que sugerente a esta escogida sección:
Alza, niña, el cobertor,
no me seas melindrosa,
que te la vengo a meter
$\mathrm{y}$ viene tiesa la $\operatorname{cosa}^{46}$.

\footnotetext{
${ }^{43}$ Miguel Manzano, Cancionero de folklore musical zamorano, Madrid, Alpuerto, 1982, núm. 463.

${ }^{44}$ Francisco Rodríguez Marín, Cantos populares españoles, Sevilla, Francisco Álvarez y Cía, 18821883, núm. 4091.

${ }^{45}$ Casal Lois, Colección de cantares gallegos, pp. 254, 247 y 198. La última canción podría ser traducida de este modo: «Hay mucho lino este año / y ha de haber mucha espina (o estopa); / debajo de tu falda... / eso es lo que a mí me presta». Las arestas del lino son la parte leñosa del lino. Aresta puede traducirse como espina y estopa.

${ }^{46}$ Agustín Clemente Pliego, Castellar de Santiago y el Campo de Montiel: historia y folklore, Ciudad Real, Diputación, 2009, p. 582.
} 


\section{Del cuplé al reguetón}

Hasta la poesía y la música popular modernas más o menos comerciales, incluso de masas, ha arribado el tópico del varón que busca el refugio caliente de debajo de las faldas de la mujer. Un viejo cuplé picante español, que han cantado con desenfado artistas como Olga Ramos y Sara Montiel, y tarareado generaciones de personas (hasta el extremo de que se ha hecho en ocasiones tradicional, según atestiguaba una versión asturiana muy fragmentaria que conocimos páginas atrás ${ }^{47}$ ), suena hoy con bríos renovados hasta en versiones (algunas muy diferentes entre sí) que pueden ser leídas, escuchadas y aún contempladas en Internet:

En la playa se bañaba

una niña angelical

y acariciaban las olas, ay...

su figura escultural.

Al entrar en la caseta

a quitarse el bañador

le decía a su bañero ¿qué?

con acento de candor...

—Tápame, tápame, tápame...

tápame, tápame, que estoy mojada...

-Para mí será taparte

la felicidad soñada.

—Tápame, tápame, tápame...

tápame, tápame, que tengo frío.

-Si tú quieres que te tape,

ven a mí, cariño mío.

Una tarde de aguacero

sin paraguas Soledad

se mojaba y la chiquilla iba

caladita ya...

Un joven la quiso entonces

con el suyo resguardar,

\footnotetext{
${ }^{47}$ La de Martínez Torner, Cancionero musical de la lírica popular asturiana, núm. 223. Recordémosla: «—Tápame, tápame, tápame, / tápame que tengo frío. / —Cómo quieres que te tape, / si yo no soy tu marido?».
} 
y llegó tan a buen tiempo

que ella dijo sin tardar:

—Tápame, tápame, tápame...

tápame, tápame, que estoy mojada...

- Para mí será taparte

la felicidad soñada.

—Tápame, tápame, tápame...

tápame, tápame, que tengo frío.

- Si tú quieres que te tape,

ven aquí, cariño mío...

He aquí lo que parecen ser unos cuantos versos abulenses y folclorizados del viejo cuplé:
Coco, recoco, coquito mío, tápame con tu dengue, tápame con tu dengue, que tengo frío $0^{48}$.

Otra canción que da fe de la popularidad, hasta ahora mismo, del tópico, es la siguiente, que, con ritmo de reguetón, a veces de cumbiatón, sirve como base a un tipo de desenfrenada gimnasia bailable que recibe el nombre de batuka, que se articula como una especie de perpetuum mobile que puede ser prolongado todo el tiempo que se quiera (tanto como dure la sesión gimnástica), y que está cada vez más difundida en el mundo hispánico. No hago mejoras ortográficas ni editoriales en el texto (solo suprimo algunas estrofas que se repiten), sacado de una de las muchas páginas y foros de Internet que están dedicados a este repertorio poético-musical, porque su escritura refleja unos códigos de cifrado y de transmisión que son muy propios y representativos del género y de su medio sociocultural. La canción (que lleva el eufemístico título de Qué tremendo $Q$, tras el que queda sugerido un Qué tremendo Qoño) puede ser escuchada en versiones diferentes. Una de ellas -para quien quiera someterse a la experiencia asombrosa, absolutamente recomendable, de la escucha- se encuentra en http://www.fotohoo.com/smyl/176310

\footnotetext{
${ }^{48}$ Eduardo Tejero Robledo, Literatura de tradición oral en Ávila, Ávila, Institución Gran Duque de Alba de la Excma. Diputación Provincial, 1994, p. 336.
} 
Que tiene Claudia debajo de la falda,

Que cuando baila el corazon se me para,

Que tiene Alicia debajo de la camisa,

Que si se agacha me late mas deprisa

Cuando la veo me tambaleo

Me da un mareo

Me veo otra vez

Ella menea su cinturita

Y mi cabezita me va a caer

Que cosa buena tu piel morena

Me tiene medio loco con su gozadera

Yo solo quiero desbocarme por su cordillera

Me gusta que lo sepas yo estoy pa' lo que quieras

Si esta buena se me desvela

Hasta las venas y me siento arder

$\mathrm{Su}$ movimiento en mi cuerpo quema

Y hasta los huesos me hace estremecer

Prende las velas con su cadera

Menéate conmigo con crema sandunguera

Y muévete suavecito como una palmera

Que no hay quien pueda resistirse al fuego de tu hoguera

Que tremendo Q

Que tremendo Q

Que tremendo cuerpo mas bello

Ay, que par de $\mathrm{T}$

Ay, que par de $\mathrm{T}$

Ay, que par de pechos yo tengo

Ay, mi Clau, mi Claudia, mi Alicia

Ay son un, son una belleza

Ay me traen, me traen de la nuca

Baila bailando Batuka

Ay que tenerla a pan vichao

Vive medio lao para mover,

Para tuquiarlas bien

Despacito y apretadito una y otra vez 
Ella me agotan, luego me azotan

Pa' mi la rubia y la morena la que me derrotan

Me gusta como esta Batuka le suben la nota

Como mueven su cadera ella se alborota

Se que lo obvio es tener una sola

Pero con ella no se que hacer

Yo la decoro, la enamoro

Y hasta la luna le voy a traer

Deboradora, arrolladora

Ay quien te viera por abusadora

Con esos cuerpos demenciales como me enamoran

Son unas nena infernales y hasta agitadoras

\section{Paraklausithyron: el amante friolero que busca el calor de la dama}

Desde la poesía y la música más rabiosamente contemporáneas regresamos ahora al pasado, porque es inevitable señalar aquí que la metáfora-motivo del varón que alega que siente frío antes de ser acogido (a veces también rechazado) en el cálido refugio femenino se corresponde con el término y con el concepto de paraklausithyron (con las raíces para 'ante', clausi 'cerrada', thyron 'puerta') que llegó casi a adquirir la categoría de género bien acuñado de la poesía erótica latina ${ }^{49}$. Sobre el tópico, que convierte la puerta en metáfora del acogedor sexo femenino que separa el frío del calor y la desesperación del amor, me he extendido ya en otro estudio ${ }^{50}$, por lo que bastará con evocar ahora unos pocos pero muy representativos paralelos. Primero, el que asoma en el Cantar de los cantares bíblico (5:2-5), con esos versos tan encendidos y tan equívocos («Mi amado metió la mano / por el cerrojo de la puerta; / al oírlo, mis entrañas retozaron...»):

Yo dormía, pero mi corazón velaba...

¡Una voz! Mi amado que llama:

-Ábreme, hermana mía, amiga mía, paloma mía, mi perfecta;

${ }^{49}$ Véase al respecto Frank Olin Copley, Exclusus amator: a study in Latin love poetry, Madison, Wis., American Philological Association, 1956,; Michael S. Cummings, Observations on the development and code of pre-elegiac paraklausithuron, tesis doctoral, Ottawa, University, 1997; y Robert J. Ball, Tibullus the Elegist: A Critical Survey, Göttingen, Vandenhoeck and Ruprecht, 1983, pp. 47-48.

${ }^{50}$ José Manuel Pedrosa, «La balada hispánica de La mujer engañada y el pahkaru indio del Sumba: tipos, motivos y paraklausithyron», Acta Poética, en prensa. 
mi cabeza está cubierta de rocío;

mis bucles, del relente de la noche...

Me he quitado ya mi túnica,

¿he de ponérmela otra vez?

Me he lavado los pies,

¿los volveré a manchar?

Mi amado metió la mano

por el cerrojo de la puerta;

al oírlo, mis entrañas retozaron.

Me levanté para abrir a mi amado, $\mathrm{y}$ mis manos destilaron mirra, mirra virgen mis dedos

en la manilla de la cerradura... ${ }^{51}$.

La lírica tradicional española de los Siglos de Oro nos ofrece testimonios preciosos del mismo tópico:
Ábreme, casada, por tu fe;
llueve menudico, y mojomés2.

Y el cancionero español moderno ha preservado, también, muchos versos que insisten sobre lo mismo:
Agua menudita llueve,
yo me mojo en tus canales,
ábreme la puerta, cielo,
que soy aquél que tú sabes ${ }^{53}$.

Esta bellísima canción asturiana añade a la metáfora-motivo del amante que pasa frío en la puerta de la amada e implora su calor, el del monte desapacible:

¡Que me oscurece!

¡Ay de mí que me oscurece

a la salida del monte!

Penosina de la aldea, dame posada esta noche.

¡Tan oscura!

\footnotetext{
${ }^{51}$ Cantar de los Cantares, en La Santa Biblia, Madrid, Eds. Paulinas, reed. 1988, pp. 790-795, p. 793.

${ }^{52}$ Sobre esta canción y su tradición, véase Frenk, Nuevo corpus, núm. 341.

${ }^{53}$ Fernando Flores del Manzano, Cancionero del valle del Jerte, Cabezuela del Valle, Cultural Valxeritense, 1996, p. 133.
} 
¡Oh qué noche tan oscura que no tiene movimiento! ¡Oh quién pudiera tener tan sereno el pensamiento ${ }^{54}$ !

Y estas otras canciones murcianas rizan el rizo, porque aúnan al amante friolero con la oportuna solicitud de «la manta y el cobertor» y de «tus enaguas»:

$$
\begin{aligned}
& \text { Échame por la ventana } \\
& \text { la manta y el cobertor, } \\
& \text { que me tienes en la calle } \\
& \text { como si fuera un ladrón. } \\
& \text { En la pompa repompa } \\
& \text { de tus enaguas, } \\
& \text { pasaría una noche, } \\
& \text { aunque me helara }
\end{aligned}
$$

\section{«Que esta noche va a llover, / ay, señora, ama, / ¿dónde dormiré?»}

Volvamos, al cabo de estos excursos necesarios para entender la tradición en que se enmarcan nuestros versos, al romance de La reina Ginebra y su sobrino, y recuperemos el diálogo en que el cínico joven (que está deseando unirse carnalmente a la reina, igual que ella está deseando unirse a él) se finge, por dos veces, helado, desvalido, ingenuo y escrupuloso:

-Toquedes vos, mi sobrino,
vuestra dorada vozina,
porque lo oyessen los míos,
qu'estauan en la montiña.
-De tocalla, mi señora,
de tocar sí tocaría,
mas el frío haze grande,
las manos se me elarian,
y ellos están tan lexos
que nada aprouecharía.
- Meteldas vos, mi sobrino,
so faldas de mi camisa.

\footnotetext{
${ }^{54}$ Martínez Torner, Cancionero musical de la lírica popular asturiana, núm. 1.

${ }^{55}$ Pascuala Morote Magán, La cultura popular de Jumilla II El cancionero popular, Jumilla, Excmo. Ayuntamiento, 1993, pp. 140 y 190.
} 
- Esso tal no haré, señora, que haría descortesía, porque vengo yo muy frío y a vuestra merced elaría.

Fijémonos en el sinuoso diálogo que se establece entre la voz femenina y la voz masculina del romance $y$, en especial, en la estructura cuasi paralelística que enlaza los versos «-Toquedes vos, mi sobrino...» con «-Meteldas vos, mi sobrino...», y «-De tocalla, mi señora...» con «-Esso tal no haré, señora...». Recurso de demora, suspensión, amplificatio, de casi dramática eficacia, que acompaña el gradual acercamiento amoroso de los dos personajes.

Pues bien: echemos ahora un vistazo a esta canción tradicional en pueblos de la provincia de Burgos, a su organización poética, y en especial

- a la ambientación en una noche lluviosa en que el hombre teme quedarse sin refugio y ruega cobijo (paraklausithyron) a la mujer;

- a las simuladas intenciones lujuriosas que se ocultan tras la cínica petición del hombre de refugio contra la lluvia;

- al diálogo en que el varón desgrana un juego ingenioso de excusas, disimulos y falsos escrúpulos, mientras se avanza en el acercamiento amoroso gradual a la mujer (en cuatro fases, no en dos, como en el romance de La reina Ginebra y su sobrino);

- a la desenvuelta franqueza con que en los versos finales consiente (o más bien anima) la dama el acceso carnal;

- y al hecho de que el joven sea un servidor y la mujer sea su señora, lo que se halla en consonancia con las posiciones sociales respectivas de la reina Ginebra y de su sobrino...

- Con el garrotín, que esta noche va a llover, ay, señora, ama, ¿dónde dormiré?

-Ya te he dicho, mozo, que duermas con las mulas.

- ¡Ay, señora ama, gastan malas pulgas!

-Con el garrotín, que esta noche va a llover, 
ay, señora, ama, ¿dónde dormiré?

-Ya te he dicho, mozo, que duermas en el pozo.

_ ¡Ay, señora ama, hay agua y me mojo!

-Con el garrotín, que esta noche va a llover, ay, señora, ama, ¿dónde dormiré?

-Ya te he dicho, mozo, que duermas con la criada. - ¡Ay, señora ama, tiene muchas legañas!

-Con el garrotín, que esta noche va a llover, ay, señora, ama, ¿dónde dormiré?

—Ya te he dicho, mozo, que duermas conmigo.

— ¡Ay, señora ama, yo también lo digo ${ }^{56}$ !

En la versión asturiana que vamos enseguida a conocer, el hombre se queja de que tiene la montera mojada, y la desprendida mujer - a la que, pese a la evidente complicidad erótica, él da el respetuoso tratamiento de 'señora'- se ofrece a recibir y a planchar (lo cual es una modalidad de calentamiento tan intensa como sofisticada) aquella prenda. ¿Cómo no recordar aquí la evocación de las manos heladas del sobrino y de las entretelas calientes de la reina Ginebra?

$$
\begin{aligned}
& \text { —iAy de la mió montera, } \\
& \text { que anoche la mojé! } \\
& \text { Dígame, señora, } \\
& \text { dónde la tenderé. } \\
& \text { Si la tiendo en la arena, }
\end{aligned}
$$

${ }^{56}$ Miguel Manzano Alonso, Cancionero popular de Burgos I Rondas y canciones, Burgos, Diputación Provincial, 2001, p. 632. 
mojada como está, ¡ay, de la mió montera, cuándo me secará!

-Cuélgala de una escarpia, yo te la plancharé, esa montera guapa que yo te regaré.

Esa montera guapa, mi querido Manuel ${ }^{57}$.

De argumento similar es una composición en metro de romance (suele recibir el título de La patrona y el militar) de la que puede ser buen ejemplo esta bastante explícita y atrevida versión extremeña, que presenta al hombre quejándose de que no tiene donde colgar su morral, otro atributo de simbólicas resonancias genitales (= testiculares). Con gran desenvoltura exige una buena cena (otra señal que en mucha literatura erótica precede al acto sexual). El que la mujer sacrifique para él una gallina que no es suya, sino «de la vecindá(d)», podría ser indicio de que es mujer casada que entrega al soldado un bien del que no debería disponer como suyo:

Ha venido un soldadito con fusil, manta y morral. — ¡Ay, dígame uhté, patrona, ¿dónde cuelgo ehte morral?

-Ahí tiene usté una estaca si le quiere uhté colgá(r). -Qué ehtaca ni qué demonio, en percha lo he de colgá(r).

Ay, dígame usté, patrona, ¿qué eh lo que voy a cená(r)?

-Unas sopitah de ajo, y eso no le ha de faltá(r).

-Qué sopah ni qué demonio, yo gallina he de cená(r).

-Lah gallinah no son míah, que son de la vecindá(d).

-Asi sean del alcalde, yo gallina he de cená(r). Ay, dígame uhté, patrona,

${ }^{57}$ Aurelio De Llano Roza de Ampudia, Esfoyaza de cantares asturianos, Oviedo, Marcelo Morchón, 1924, núm. 718. 
¿adónde me voy a acohtá(r)?

-Ahí tiene usté una halda, y súbase uhté al pajá(r).

- Qué pajar ni qué demonio, yo con uhté m'he de echá(r).

A eso de los nueve meseh

la patrona mala ehtá;

ha tenido un soldadito

con fusil, manta y morral.

A ehto de los ocho añoh

pregunta por su papá.

—Qué papá ni qué demonio, tu papá en la guerra ehtá; y cuando le den licencia, él pehcará y se vendrá ${ }^{58}$.

Antes de dar por cerrado este capítulo dedicado a las composiciones tradicionales modernas, conviene advertir que el tipo de canción seriada y paralelística que ha ocupado nuestra atención en las últimas páginas encuentra, también, algún correlato sumamente interesante en lenguas y en tradiciones no hispánicas. Véase, por ejemplo, esta canción de vendimia tradicional en la comarca francesa de Nantes, que insiste sobre varios de los tópicos que nos resultan ya tan conocidos: las intenciones lujuriosas que se ocultan tras las cínicas peticiones del hombre; el acercamiento gradual (esta vez en cuatro fases) a la mujer; la desenvuelta franqueza con que es planteada la cuestión de la unión carnal en los versos finales; el hecho de que el hombre sea un ciego mendicante y la mujer una dama de condición más elevada...:

—Donnez-lui à boire, donnez lui du pain a ce pauvre aveugle qui n'y voit plus rien.

-Pauvre aveugle, voulez-vous du pain (bis)?

-Non, Madame, mon bissac est plein (bis).

-Pauvre aveugle, voulez-vous du vin (bis)?

-Non, Madame, mon bidon est plein (bis).

-Pauvre aveugle, que désirez-vous (bis)?

-Oh! Madame, coucher avec vous (bis).

-Pauvre aveugle; vous n'y verrez rien (bis).

-Oh! Madame, je sentirai bien (bis) ${ }^{59}$.

${ }^{58}$ Bonifacio Gil, Cancionero popular de Extremadura I, 2. ${ }^{\text {a }}$ ed. Badajoz, Diputación, 1961, I, pp. 110-111.

${ }^{59}$ Théo Staub, L'enfer érotique de la chanson folklorique française, 2 tomos en 1 volumen, Cergy, Édi- 
He aquí la traducción:

—Dad de beber, dad algo de pan

a este pobre ciego que no ve.

-Pobre ciego, ¿queréis pan (bis)?

-No, señora, que mi saquito está lleno (bis).

-Pobre ciego, ¿queréis vino (bis)?

-No, señora, que mi cantimplora está llena (bis).

-Pobre ciego, ¿qué es lo que deseáis (bis)?

— iOh, señora, acostarme con usted (bis)!

- Pobre ciego, pero si no verás nada (bis).

— ¡Oh, señora, pues bien que lo sentiré (bis)!

\section{«Cuanto más se moja el conejito, más duro se pone el pajarito»}

No solo la poesía tradicional ha dado muestras de predilección, desde hace siglos, por argumentos protagonizados por varones (en general de humilde condición social) que intentan acercarse gradualmente (observando, no sin cierto cinismo, todo tipo de fingidas prevenciones y escrúpulos) a mujeres de condición más elevada, y que al final se ven sorprendidos por el franco entusiasmo erótico de ellas. Hay también prosas que desarrollan mil y una variaciones en torno al mismo asunto. En otro artículo me he ocupado, por ejemplo, del cuento III:1 de El Decamerón, que relata, según el título que le puso el propio Giovanni Boccaccio, cómo Masetto de Lamporecchio se finge mudo y entra como hortelano de un monasterio de monjas, y todas se disputan el acostarse con él $l^{60}$. El elenco de desarrollos y reminiscencias de este tipo cuentístico (y de otros conexos) es tan denso y heterogéneo que su análisis nos extraviaría por vericuetos a los que ahora no nos podemos ni asomar.

Tendremos que limitarnos ahora a quedarnos en las cercanías de los tópicos y de las combinaciones de tópicos que de forma más concreta nos están ocupando. Y en esas cercanías encontramos este sorprendente cuento de animales registrado en la provincia de Salamanca, con su paraklausithyron, con su amante mojado y su lluvia en el exterior, con su diálogo lleno de ambigüedades y dobles sentidos picantes, con sus requiebros e insistencias... $\mathrm{Y}$ con su desenlace, que aunque parece a primera vista muy frustrante y

\footnotetext{
tons d'Aujourd'hui, 1981, tomo II, p. 179.

${ }^{60}$ José Manuel Pedrosa, «El hortelano en el jardín de las monjas (Boccaccio, El Decamerón, III:1)», en Relecturas de Boccaccio: narrativa de los Siglos de Oro, cine y teatro, eds. María Hernández Esteban, Marcial Carrascosa Ortega y Mita Valvassori, [Cuadernos de Filología Italiana. Vol. extra (2010)], Madrid: Universidad Complutense, 2010, pp. 145-162.
} 
completamente apartado de los demás que hemos conocido, queda aliviado por una moraleja de alto voltaje erótico que da la impresión de que la última palabra de ese picante juego que ha sido entablado está todavía por decir:

Estaba lloviendo. Y entonces, llegaba el conejito y le decía:

-Venga, pajarito, déjame entrar, que tú estás cobijao. Déjame entrar. Que, que yo me estoy mojando.

Y el pajarito.

- iQue no te dejo entrar, hombre! ¡Te he dicho que no te dejo entrar!

— ¡Venga! -el conejito-. Venga, que me estoy mojando, ¡hombre!, que... Déjame entrar, por favor.

- Te he dicho que no te dejo.

Y se ponía ya..., el pájaro se ponía duro, se ponía fuerte:

- Te he dicho que no te dejo entrar.

Y... el conejito, venga a mojarse, venga a mojarse:

— iVenga!, por favor, pajarito...

- Que te he dicho que no te dejo.

Moraleja, ija, ja, ja! Moraleja:

Cuanto más se moja el conejito, más duro se pone el pajarito ${ }^{61}$.

Una cancioncilla gallega con muy sugerentes saya y pájarito pone amable contrapunto al cuento abulense:

Si me dás ó chirlo-mêrlo

que tapas co-á tua saya, douch'ó meu xílgaro macho que teño dentro d'a xaula ${ }^{62}$.

\section{De la tradición oral tzotzil de Chiapas a la quechua de Perú}

Aventurémonos ahora por geografías y tradiciones inesperadamente exóticas. En primer lugar, por la de los indios tzotliles de Chiapas, que en uno de sus desbordantes juegos de bombas (una especie de canciones-músicasdanzas festivas y rituales) ${ }^{63}$, intercambian estrofas tan sugestivas como éstas:

${ }^{61}$ El cuento me ha sido facilitado por su colector, Luis Miguel Gómez Garrido, quien lo registró a Román Vicente Sánchez, natural de Pizarrales (Salamanca), de 49 años de edad, en Salamanca el 26 de febrero de 2009.

${ }^{62}$ Casal Lois, Colección de cantares gallegos, p. 200.

${ }^{63}$ Sobre el género de las bombas, véase José Manuel Pedrosa, «Las bombas: un género de canción y de danza en las tradiciones mexicana y panhispánica», Revista de Literaturas Populares, 1 (2001) pp. 
¡Mariquita, no te vayas a un lado!

Te tengo oro;

[te] tengo plata.

Tu piernita me gusta mucho.

¡Bomba!

Ay, Mariquita,

ábreme tu[s] piernita[s],

porque ya me estoy muriendo de frío.

¡Bomba!

¡Esta muchacha muy alegría!

¡Aunque me llega día y noche [noche y día], sale uno ${ }^{64}$ !

Puede, en cualquier caso, que el texto más interesante y asombroso de todos los que nos ha tocado y nos va a tocar conocer sea un cuento en lengua quechua que fue registrado en las remotas alturas de Caylloma, en Arequipa (Perú), y que presenta una típica escena de paraklausithyron en que el varón (encarnado aquí en un zorro) acaba teniendo franco acceso sexual a una mujer adúltera tras cumplir el consabido requisito (esta vez en cinco fases) de las excusas cínicas. He aquí la traducción al castellano:

\section{El zorro y la mujer adúltera}

Cuentan que antiguamente vivía en la puna una mujer con su marido. Dicen que su perro era un zorro. Cada vez que el marido estaba de viaje, este zorro aprovechaba para hablar con ella.

Una ocasión, el marido salió de viaje con las llamas y dejó a su mujer con el zorro-perro. El zorro dormía siempre afuera, pero cuando el marido se ausentaba en sus viajes el zorro dormía dentro de la casa. Y así fue como el zorro se tiraba cada día a la mujer. ¿Cómo lo hizo? Así: la mujer dijo al zorro:

-Duérmete afuerita.

El zorro dijo:

—No, mamita, afuera no puedo dormir. «¡Fuera, fuera!», me dirían. Mejor dormiré adentro nomás.

Entonces la mujer dijo:

157-187. http://www.rlp.culturaspopulares.org/textcit.php?textdisplay=213\&batchdisplay

${ }^{64}$ Victoria Reifler Bricker, Humor ritual en la altiplanicie de Chiapas, México, Fondo de Cultura Económica, reed. 1986, pp. 76-81. 
-Duérmete pues en ese rinconcito.

—No, no. «¡Rincón, rincón!», me dirían.

-Entonces al lado de la puerta.

—No, no... «iPuerta, puerta!», me dirían.

-Entonces al ladito del fogón:

—No, no... «iFogón, fogón!», me dirían.

La mujer, ya impaciente, le dijo:

— ¿Dónde pues te quieres dormir?

El zorro contestó:

—Lo que es yo, me sé dormir encimita del puputi de mi mamá.

Entonces la mujer dijo:

- Bueno, ven pues, duérmete nomás aquí encimita de este puputi.

El zorro se acercó muy contento y así empezaron a fornicar todas las noches.

Una noche mientras estaban encamados, se escuchó el ruido de la campanita de las llamas; el marido estaba regresando. Entonces la mujer dijo al zorro:

—Levántate, apura, ¡sal! ¡Ya está ahí mi esposo!

Al zorro, por el susto, se le había atracado el sexo entre las piernas de la mujer. Era como si se le hubiera hecho una bola, y no conseguía sacarlo.

Mientras tanto, el marido ya estaba en el patio.

-Ya, mujer, ¡carajo! ¡Apura, levántate! ¡Ayúdame a descargar las llamas!

La mujer, asustada, al ver que nada podía hacer, agarró un cuchillo y le cortó el sexo al zorro, quien se quejó diciendo «ñis, ñis», al tiempo que salía huyendo.

Ella, con el miembro todavía entre las piernas, salió rápidamente a ayudar a su marido.

Cuando acabaron de descargar las llamas entraron a la casa, y entonces, el zorro comenzó a pedir insistentemente desde la puerta:

— ¡Mamita, devuélveme mi oca!

El hombre preguntó a su esposa:

— ¿Qué oca has agarrado de ese perro?

Tanto y tanto pedía el zorro su oca que el hombre, muy amablemente, le preguntó:

— ¿Qué oca ha agarrado esta mujer?

El zorro, sin poder aguantar el dolor, dijo:

- ¡La tiene entre las piernas, papito! ¡La tiene entre las piernas, papito!

Entonces el hombre buscó entre las piernas de su mujer y encontró el miembro del zorro. Se lo arrojó, y el zorro, lamiéndose bien, se lo volvió a pegar como lo tenía antes. Entre tanto el hombre le dio una paliza de muerte a su mujer.

Tras esto el zorro desapareció y ya nunca más volvió a ser perro para la gente. Mas bien, desde entonces, los perros odian a los zorros ${ }^{65}$.

${ }^{65}$ Andrés Chirinos Rivera y Alejo Maque Capira, Eros andino, Cusco, Centro de Estudios Regionales Andinos Bartolomé de Las Casas, 1996, pp. 286-288. 
Como es fácil apreciar, este deslumbrante relato tradicional quechua peruano está estructurado en dos partes muy bien definidas: la primera va desgranando, con ironía e histrionismo que intentan hacer pasar al pícaro por inocente, las fases del acercamiento sexual entre el zorro y la mujer, de acuerdo con una estructura cuasi formulística que nos resulta ya perfectamente familiar, después de todos los paralelos que han ido pasando ante nuestros ojos. La segunda parte es otra versión, interesantísima -volveremos en algún trabajo próximo sobre ella- del complejo de relatos acerca de vaginas dentadas que es posible documentar en tradiciones orales dispersas por muchos lugares del mundo.

\section{El motivo K1361 y el tipo 900A*}

El extraordinario cuento peruano en lengua quechua de El zorro y la mujer adúltera que acabamos de conocer nos acerca a una serie de motivos narrativos que han sido etiquetados de este modo en el monumental catálogo de motivos folclóricos de Stith Thompson:

K1361: Mendigo compra el derecho a dormir a la puerta de la habitación de la muchacha, a los pies de la cama, en la cama.

K1361.2: Gradual compra de favores: progresión anatómica ${ }^{66}$.

Fijémonos bien en la primera parte del enunciado del primer motivo: «Mendigo compra el derecho a dormir a la puerta de la habitación de la muchacha». Según se ha convertido ya en costumbre para nosotros, desde los episodios de Dido y Ginebra hasta aquí, vuelve a salirnos al paso el tópico del hombre de ínfima condición (rasgo que queda fuertemente recalcado) que se acerca al cuerpo expectante de la dama de mayor alcurnia. Fijémonos también en la segunda parte del mismo enunciado, que describe el acercamiento «a la puerta de la habitación de la muchacha, a los pies de la cama, en la cama». Una vez más, los conceptos de gradualidad y de progresión se muestran fundamentales en la articulación de la estructura de nuestros versos y prosas acerca de varones (de baja condición) que buscaban el trato carnal con mujeres de condición más elevada que la suya y de trato inesperadamente desenvuelto.

Análoga estructura narrativa (aunque ya no se combine, por lo general, con el tópico del paraklausithyron) detectamos en el tipo cuentístico que tie-

${ }^{66}$ Traduzco de Stith Thompson, Motif-Index of Folk Literature: a Classification of Narrative Elements in Folktales, Ballads, Myths, Fables, Mediaeval Romances, Exempla, Fabliaux, Jest-Books and Local Legends, ed. rev. y aum., 6 vols., Bloomington \& Indianapolis-Copenhague, Indiana UniversityRosenkilde \& Bagger, 1955-1958. 
ne el número $900 \mathrm{~A}^{*}$ en el catálogo universal de cuentos de Aarne-Thompson, en el que aparece resumido de este modo sumamente escueto, que no hace justicia a los desarrollos narrativos del tópico que a nosotros ahora nos interesan, pero en el que vuelve a jugar un papel clave el hecho de que el varón sea pobre y la dama rica:

El novio rechazado: dos amigos acuerdan que, si uno tiene un hijo y el otro una hija, los harán casar; pero el padre de la muchacha rechaza al hijo de su amigo como novio de su amiga cuando éste se vuelve pobre. El muchacho posee carbones que dan luz por la noche y se los da a la muchacha a condición de que ella le muestre sus pies y luego de que se acueste con él una noche. Así consigue poseer algo que pertenece a la muchacha (parte de su cabello, etc.), y solicita, el día en que ella se va a casar con otro, que su compromiso sea respetado, y muestra el cabello que pertenece a la muchacha. El novio desiste de casarse, y la muchacha se esposa con el héroe ${ }^{67}$.

Julio Camarena y Maxime Chevalier consignaron en su monumental catálogo de cuentos panhispánicos varias versiones españolas, hispanoamericanas, catalanas, gallegas y portuguesas del cuento tipo 900A*. En un estudio que acerca de este relato publiqué yo hace algunos años ${ }^{68}$ ofrecí más versiones (algunas africanas de enorme interés) del tipo cuentístico 900A*. La gran mayoría de ellas muestra al hombre pobre acercándose y poseyendo progresivamente, pasito a pasito, el cuerpo de la dama rica, que nunca hace demasiados ascos al acoso amoroso del desenvuelto joven.

Colofón felicísimo el de este cuento, con dama distinguida que al final se entusiasma con el intercambio erótico con el joven de humilde extracción, que nos permite cerrar, al menos de momento, el elenco de paralelos cercanos y lejanos del romance de La reina Ginebra y su sobrino que conocimos al principio con un relato que nos devuelve a la relación de un hombre y de una mujer que van organizando su acercamiento sexual de manera demorada, paulatina, envolviendo cada paso adelante en juegos de palabras y de metáforas de gran sutileza que, al final, estallan en una incontenible manifestación de pasión que involucra por igual a las dos partes.

Es obvio que nuestro dilatado itinerario tras las huellas y ecos de estos

${ }^{67}$ Traduzco de Antti Aarne y Stith Thompson, The Types of the Folktale: a Classification and Bibliography [FF Communications 184] 2. ${ }^{a}$ revisión, Helsinki, Suomalainen Tiedeakatemia-Academia Scientiarum Fennica, 1981, núm. 900A*.

${ }^{68}$ José Manuel Pedrosa, «El cuento ndowe de El pájaro y la princesa embarazada (AT 900A*), dos poemas de Catulo y dos cuentos del Decamerón de Boccaccio: de la literatura comparada a la antropología», De boca en boca: estudios de literatura oral de Guinea Ecuatorial, coord., J. Creus, Vic, Ceiba, 2004, pp. 195-217. 
romances, de estas canciones, de estos cuentos en que hay ensamblados motivos narrativos flotantes, migratorios, sutilmente metafóricos a veces, brutalmente explícitos otras, habrá quedado sembrado y va a seguir siempre lleno de lagunas, interrogantes y problemas, como es inevitable que suceda en el terreno siempre irregular y dinámico, tantas veces en penumbras (cuando no en sombras), de una literatura que se halla en la frontera difusa entre lo oral y lo escrito, donde son muchísimas más las palabras que se ha llevado el viento que las que han llegado hasta nosotros.

En cualquier caso, alcanzar (como parece que hemos alcanzado) a fijar el perfil de un topos poético capaz de integrar una pluralidad de metáforasmotivos narrativos que se combinan de manera más o menos regular en épocas y en lugares tan diversos puede entenderse como un cierto progreso en la tarea a la que debemos intentar ser fieles los filólogos de mejor aprehender y definir el concepto de tradición literaria.

No cabe duda de que la acotación de esta familia de relatos protagonizados por un hombre (por lo general de humilde condición) y por una mujer (por lo general de condición elevada) que consuman ardorosamente su unión carnal -en la frontera que separa un escenario selvático, tempestuoso, frío, de otro interior, acogedor y caluroso- al cabo de un diálogo lleno de falsos escrúpulos y de sutiles eufemismos que van marcando las fases de su acercamiento nos permite entender de otra manera, seguramente más consciente y profunda, el amplísimo elenco de textos que han ido desfilando ante nosotros: cruces extrañamente dúctiles e intensos de metáforas y de motivos, piezas constitutivas de fascinantes mecanos verbales que participan a un tiempo de lo lírico y de lo narrativo, eslabones, a veces muy parecidos, otras relativamente discrepantes, breves y parciales unos, muy desarrollados y articulados otros, de la cadena de una tradición lírico-narrativa que ha tenido una presencia persistente, inmemorial, en el imaginario humano. 


\section{$\cos 8$}

RESUMEN: Reflexión sobre los rasgos comunes de la metáfora y del motivo, a partir de una gran cantidad de textos literarios, orales y escritos, antiguos, (desde la Eneida) y modernos que están protagonizados por una mujer de elevada condición y por un hombre de condición inferior que tienen relaciones amorosas en un escenario campestre o silvestre, en mitad de una tormenta que les obliga a buscar refugio y calor.

ABSTRACT: This article presents an analysis of common features of metaphors and motifs, based on a study of many literary texts, both oral and written, ancient (beginning with the Aeneid) and modern, whose main character is a woman of a higher position and a man of a lower position who have a sexual relationship in the countryside because a storm forces them to look for a refuge and warmth.

Palabras clave: Motivo. Metáfora. Tipo. Romance. Canción. Cuento. Oralidad. Escritura. Eneida.

Keywords: Motif. Metaphor. Type. Ballad. Song. Tale. Orality. Literacy. Aeneid. 